University of Nebraska - Lincoln

DigitalCommons@University of Nebraska - Lincoln

\title{
All Parents Are to Blame (Except This One): Global Versus Specific Attitudes Related to Parental Responsibility Laws
}

\author{
Eve M. Brank \\ University of Nebraska-Lincoln, ebrank2@unl.edu \\ Stephanie A. Hays \\ University of Florida \\ Victoria Weisz \\ University of Nebraska-Lincoln, vweisz1@unl.edu
}

Follow this and additional works at: https://digitalcommons.unl.edu/psychfacpub

Part of the Psychiatry and Psychology Commons

Brank, Eve M.; Hays, Stephanie A.; and Weisz, Victoria, "All Parents Are to Blame (Except This One): Global Versus Specific Attitudes Related to Parental Responsibility Laws" (2006). Faculty Publications, Department of Psychology. 552.

https://digitalcommons.unl.edu/psychfacpub/552

This Article is brought to you for free and open access by the Psychology, Department of at DigitalCommons@University of Nebraska - Lincoln. It has been accepted for inclusion in Faculty Publications, Department of Psychology by an authorized administrator of DigitalCommons@University of Nebraska - Lincoln. 
Published in the Journal of Applied Social Psychology (2006) 36(11): 2,670-2,684. Copyright 2006, Wiley. Used by permission.

\title{
All Parents Are to Blame (Except This One): Global Versus Specific Attitudes Related to Parental Responsibility Laws
}

\author{
Eve M. Brank ${ }^{1,3}$, Stephanie A. Hays ${ }^{1}$ and Victoria Weisz ${ }^{2}$ \\ ${ }^{1}$ Department of Criminology, Law, and Society, University of Florida, \\ Gainesville, Florida, USA \\ ${ }^{2}$ Center on Children, Families and the Law, University of Nebraska-Lincoln, \\ Lincoln, Nebraska, USA \\ ${ }^{3}$ Corresponding author; affiliation 2009- : Department of Psychology, Uni- \\ versity of Nebraska-Lincoln, Lincoln, Nebraska, USA
}

Increasing state legislation and media interest give the appearance of public support for parental responsibility laws; however, some national polls suggest otherwise. Based on disparate global and specific attitudes in other areas of the criminal justice literature, it was hypothesized that relatively weak global support for parental responsibility would be diminished even more if a specific juvenile was described. The current studies confirmed that participants were even less supportive of parental responsibility laws when a specific juvenile and his parents were described than they were when they answered questions about parents in general.

In a recent New York. Times editorial, a New York police lieutenant made the statement "No governmental programs or police intervention can substitute for loving parental supervision. Children need that to become mature, healthy adults. If you're a mother or father, it should be you there watching your teenagers, not me frisking them for weapons" (McHugh, 2003, p. A11). This assertion was made in response to the police lieutenant's personal involvement with a "stabbing frenzy" in a South Bronx roller rink that left a security guard critically injured and eight other people wounded (Elliott, 2003).

Acknowledgment: The authors thank Lonn Lanza-Kaduce, Marc Pearce, Cassandra Volanges and Kevin O’Neil for their contributions to this research. 
McHugh (2003) is not alone in his desire for parental involvement. In fact, criminologists posit that even minimal supervision by an adult is often all that is required to deter crime among children (Hirschi \& Gottfredson, 1993). Some claim that the law should require this supervision and that only through legislatively required parental responsibility will an answer to juvenile crime be found (Zolman, 1998). The lawmakers and courts have answered this call by enacting or enforcing various forms of parental responsibility when children commit crimes. For example, Anthony and Susan Provenzino were convicted of a criminal misdemeanor under a city ordinance that required them to control their son after he was convicted of burglary and a drug offense (Meredith, 1996).

Indeed, parental responsibility and involvement laws have developed as a proposed answer to juvenile delinquency (Davidson, 1996). Across the nation, media reports like those mentioned earlier are filled with stories of children committing crimes and the parental responsibility (or lack of it) for the child's criminal behavior. Despite apparent public support for parental responsibility laws, few empirical studies have gone beyond broad general polls to examine public attitudes toward punishing parents in specifically defined situations.

The current research will do just that by focusing on attitudes toward parental responsibility in specific, as compared to global, situations. First, we will outline the different forms of parental responsibility laws. Second, we will present what little public attitude research has been conducted in the area of parental responsibility. Third, we will discuss the discrepancy between global and specific attitudes as found in other research areas. Finally, we will use the current studies to examine if there is a global and specific discrepancy in the area of parental responsibility.

The current juvenile justice system appears to be conflicted between its original goal of rehabilitation and its current emphasis on retribution. Gardner (2003) proposed four main factors that have led to this erosion of the original juvenile court intentions. First, in order to protect juveniles from unfair exercises of state power, the juvenile court adjudication process has been adjusted to resemble adult criminal court more closely (see Breed $v$. Jones, 1975; In re Gault, 1967; In re Winship, 1970; Kent v. United States, 1966). Second, there is a perception that the juvenile court system has failed to meet its intended objective of rehabilitating juveniles (Feld, 1991, 1999; Moon, Sundt, Cullen, \& Wright, 2000). Third, the public believes that serious juvenile crime is increasing (Moon, Sundt et al., 2000). Fourth, social science research has suggested that older juveniles (16- and 17-year-olds) have similar competency levels to those of young adults (18- to 24-year-olds) on a number of different dimensions (Grisso et al., 2003). 
At the same time juvenile courts are becoming more like adult courts, new laws are being enacted that place blame and responsibility on juveniles' parents. These parental responsibility laws are inconsistent with the trend toward a more punitive juvenile court. On the one hand, juveniles are being told that they are just as responsible as adults and therefore will be treated like adults. On the other hand, parental responsibility laws tell juveniles that their parents should be involved in their cases because, in some way, the parents are responsible for juveniles' delinquency.

Parental responsibility laws come in three main forms: (a) civil parental liability; (b) contributing to the delinquency of a minor; and (c) required or encouraged parental involvement in a juvenile case (Brank, Kucera, \& Hays, 2005). Under civil liability, a plaintiff may bring a case against the parents for property damage or personal injury (Hanson, 1989). Under contributing to delinquency, the guardian or other adult may be held criminally responsible for contributing to the delinquency of a minor (Geis \& Binder, 1991). Required or encouraged parental involvement statutes are based on legislative efforts to make parents more involved in the juvenile court process and include such things as ordering parents to pay for court costs, to pay restitution, to pay for treatment costs, and to participate in the juvenile's case. In some states, failure to comply with parental involvement requirements can lead to greater punitive sanctions (Brank et al., 2005).

Media portrayals have suggested that there would be an overwhelming level of support for parental responsibility laws. Much like the stories mentioned at the beginning of this article, examples abound of the public outcry against parents of juveniles who commit crimes. Michael Shoels, father of one of the 1999 Columbine High School victims said at a public rally in New York, "They ask us if we blame the parents? Who else do we blame? I taught my son right from wrong. My son wasn't shooting people up. My son was in the library doing what he was supposed to do" (Belkin, 1999, p. 61). The attorney representing the Shoels in their civil suit against the parents of the Littleton, Colorado shooters said that bringing a case against these parents enabled him to have subpoena power to ask the parents what happens when a juvenile shoots his classmates. He claimed that the parents are the ones who know and the only ones who can explain it to the rest of us (Belkin, 1999).

Beyond media anecdotes, national polls have indicated that the public supports some form of parental responsibility. Questions concerning parental responsibility were included as part of a USA Today/CNN/Gallup poll in 1999. When they were asked to indicate who carried a "great deal of blame" for the Columbine shootings, about half of the 659 respondents included the 
parents as one of the blameworthy. Respondents gave similar weight to television, movies, music, and social pressures on youth. Similarly, a 1999 survey found that $49 \%$ of 2,000 adults who were sampled thought that the difficulties facing kids today are the result of irresponsible parents (Public Agenda Online, 1999). A national 1999 Gallup Organization telephone survey (Brank \& Weisz, 2004) found that public attitudes regarding parental responsibility were quite supportive, with nearly $70 \%$ of respondents indicating that the parents, in addition to the juvenile, are responsible when a teenager commits a crime. Peers as a responsible party came in a distant second.

Thus far, questions measuring public opinion have been brief, poll-type questions that ask for a response concerning general attitudes toward all parents. Thus, it is unclear whether national polls provide us with a true measure of public opinion or whether the question type predicts the outcome. Roberts (2003) suggested that asking global, poll-type questions could be misleading in demonstrating true attitudes. In response to global questions, respondents have a tendency to construct mental images of the worst possible offender (Roberts, 2003). In contrast, when a specific offender or offense is described, respondents' attitudes will be variable (Cann, Calhoun, \& Selby, 1980; Hollin \& Howells, 1987).

Studies of this inconsistency between global and specific attitudes have been performed across a number of different areas. Applegate, Cullen, Turner, and Sundt (1996) demonstrated that the public's general endorsement of recidivist statutes (e.g. "three strikes and you're out") was greatly reduced when they were provided with specific situations that were covered pursuant to these laws. Analogous results were found in response to questions about the juvenile death penalty (Moon, Wright, Cullen, \& Pealer, 2000), crime policy, punishment, and rehabilitation (Applegate, Cullen, \& Fisher, 2002). Researchers have found similarly inconsistent attitudes among the Canadian public. Responses to global, poll-type questions portrayed the public as wanting a more punitive justice system; however, responses to specific sentence decisions were closely akin to current judicial decisions on the same issue (Cumberland \& Zamble, 1992; Zamble \& Kalm, 1990).

This inconsistency of global attitudes being more punitive than specific attitudes is relevant because lawmakers traditionally only have global attitudes and make policy decisions based on that information (Applegate et al., 1996). Thus, the current research explores global, as compared to specific, support for parental responsibility. As with the three-strikes laws, might people be supportive of parental responsibility on a global level, but not as much on a specific case level? 
Respondents may react favorably to polls or referendums asking whether they support the concept of parental responsibility because the issue evokes an image of juveniles who have had poor parental influences. Nonetheless, when these same respondents are provided the opportunity to apply parental responsibility to specific situations, they might be less likely to do so. Additionally, prior global versus specific research has focused on attitudes toward personal responsibility. In other words, the research has focused on attitudes toward an offender or the appropriateness of a punishment for that particular offender. Will the same global versus specific effect occur when the attitude is focused on responsibility for another person's actions?

The current research explores global and specific support for underlying notions of parental responsibility laws in the United States using a pre-and post-test design. The current study was motivated by a related pilot study. The pilot study was conducted as part of a larger research program. The pilot study examines support of parental responsibility and punishment for a specifically described juvenile and his parents. Findings from that study suggested a possible difference between the attitudes displayed in global national polls and those presented when a specific case is described. As a result, the current study examines global and specific support together by using a preand post-test design. The pilot study will be described briefly, followed by a more in-depth description of the current study.

Pilot Study: Specific Attitudes in a Murder Case

Method

Undergraduate students at a midwestern university and a western community college participated in an Internet-based experiment on the issue of capital punishment to fulfill partially a course research requirement or for extra credit. Participants logged onto a website where they read case facts and answered questions. Their answers, along with the length of time it took them to complete each page, were saved immediately into a data file. There were 585 participants (226 male, 359 female; $\mathrm{M}$ age $=21.2$ years, $\mathrm{SD}=5.59$ ) who completed the experiment, but data from only 278 are relevant for parental responsibility issues because the other half were assigned randomly to receive a case manipulation involving an adult defendant.

The case facts described a defendant, Adrian Simmons, who killed a bank teller in the process of trying to rob a bank. To make the description more 
real, a picture of a 14-year-old White male was included. Simmons' family life was described as follows:

The Simmons family has been in a precarious financial situation for some time. They often have trouble paying for medical care, entertainment, and anything above their basic needs. Bill collectors call the Simmons' house regularly. The Simmons children have recently been teased at school because their clothes are old and "not cool."

Participants were asked to indicate their agreement level on a 7-point scale for five parental responsibility questions, with higher scores indicating greater agreement. The five statements are "Adrian Simmons' parents are responsible for his criminal activity" (parents responsible); "In addition to Adrian Simmons' punishment, his parents should be punished" (punished); "An appropriate punishment for Adrian's parents is a fine" (fine); "An appropriate punishment for Adrian's parents is community service" (community service); and "An appropriate punishment for Adrian's parents is imprisonment" (imprisonment). Various factors were manipulated that relate to the larger research project and did not affect responses for the parental responsibility questions statistically. Therefore, they will not be described here.

\section{Results and Discussion}

Support on the parents-responsible question was quite low. On a scale ranging from 1 (completely disagree) to 7 (completely agree), the mean response was $3.28(\mathrm{SD}=1.49)$. Approximately $78 \%$ of respondents chose 1,2 , or 3 as their agreement rating. Participants also were asked about punishment for the described juvenile offender and his parents, and the mean agreement rating was 2.58 (SD = 1.40). When asked about the different types of punishment for Adrian's parents, there was a hierarchy of support, with the most agreement being for community service $(\mathrm{M}=2.95, \mathrm{SD}=1.67)$, the next was a fine $(\mathrm{M}$ $=2.57, \mathrm{SD}=1.69)$, and the least was imprisonment $(\mathrm{M}=1.78, \mathrm{SD}=1.15)$. Nonetheless, all of the punishment options garnered low agreement ratings, with the majority of respondents indicating strong disagreement with each type. Any significant differences between the punishment options would represent merely a statistical, rather than a practical difference.

Punishing the specific parents portrayed in the case description garnered little support. Respondents preferred community service for Adrian's parents, rather than fines and imprisonment, but that preference was weak. The 
preference seemed to be for no sanctions at all for the parents. In order to determine if this lack of support was a reflection of the difference between global versus specific attitudes, the next study is designed to enable more precise comparisons. The study specifically examines global pre-stimulus attitudes, compared to specific post-stimulus attitudes.

\section{Current Study: Global and Specific Attitudes in an Assault Case}

The previously described study was the first attempt to examine attitudes toward parental responsibility issues as they apply to a specific set of facts and a specific set of parents. Although part of a larger study on an unrelated topic, the results suggest a possible discrepancy between global and specific attitudes toward parental responsibility. Employing this study as a pilot study allows for an evolution of the case description and the questions.

Based on global and specific research in other areas of criminal justice, we hypothesize that respondents will be more supportive of parental responsibility issues with global questions than with the specific case description. In addition, the case descriptions are varied, based on a manipulation of premeditation. Premeditation is included because of the possible influence of that case characteristic and its relationship to impulsivity.

Psychological research has demonstrated the negative correlation between impulsivity and premeditation. In fact, lack of premeditation is the strongest and most widely represented component of impulsive behavior (Whiteside \& Lyman, 2001). This contrasting link between premeditation and impulsivity also is recognized as a widely accepted legal principle (Brink, 2004). For instance, premeditation is a required element of first-degree murder and can be a factor of consideration in a decision to transfer a juvenile to the adult system (Brink, 2004). Statutes require that a defendant who has premeditated a crime will be found more culpable and assigned more responsibility. Therefore, it is believed that a crime described as premeditated will influence notions of responsibility. Based on previous research and legal doctrines, it is clear that responsibility attributed to the youth should increase if the described crime was premeditated. It is our belief that those participants who read about the premeditated crime will view the parents as less responsible and less blameworthy because the youth would be seen as less impulsive and, therefore, more individually culpable. 
Method

\section{Participants}

Undergraduate students at a large southeastern university volunteered to participate in the current research. No monetary or course compensation was provided. The participants were 168 students (32 male, 136 female; $\mathrm{M}$ age $=$ 20.94 years, $\mathrm{SD}=2.73$ ).

Materials and Design

Participants were given a three-page packet that includes global questions about parental responsibility, a short description of a case, and questions about the specific parent's responsibility (presented in that order). The global questions begin with a question from the national Gallup poll (Brank \& Weisz, 2004). Participants were asked "When a teenager commits a crime, which of the following is most responsible, in addition to the teenager?" Participants chose from the options of parents, peers, media, and school.

Participants also were asked to rate their agreement with three statements on a 5-point scale ranging from 1 (strongly disagree) to 5 (strongly agree). The statements are "Parents are to blame when their child breaks the law" (blame); "Parents are responsible when their child breaks the law" (responsible); and "Parents should be punished when their child breaks the law" (punish). Participants then were asked "In general, what punishment(s) is appropriate for parents of juveniles who commit crimes?" They were given the following five alternatives: no punishment, monetary fine, prison sentence, victim restitution, or other (which they were to specify).

The case facts describe a 15-year-old juvenile, Joseph T., who mugged a man to get his wallet by hitting the man on the back of his neck with the pipe, causing 6 weeks of hospitalization and rehabilitation. The case description came in two different forms. Joseph was described as having taken the metal pipe from his home with the intention of mugging someone (pre-meditated) or finding the metal pipe while walking home from a friend's house and only deciding to mug the victim while helping the man with a suitcase (no premeditation). These conditions were assigned randomly to participants during data collection. 
The rest of the case description was the same, with Joseph having one minor incident on his record. The incident involved stealing a late-model car and returning it unharmed. Joseph was described as completing community service for this prior incident. In the remaining portion of the description, Joseph's living arrangements and parent reactions are described as follows:

Joseph's father describes Joseph as being an independent child who usually keeps to himself. Joseph recently moved into a room over the family's garage. The room is much like an apartment. The room does have a small kitchen that Joseph uses about half of the time, but he eats with his parents the rest of the time. The garage apartment is connected to the house in such a way that Joseph must walk through the house to come and leave. Joseph still has a curfew, but once he is in his room, his parents say that he is able to do whatever he wants. Both of his parents are quite shocked that Joseph would ever hurt anyone.

After reading the case description, participants answered a premeditation manipulation-check question and a series of specific questions that are complementary to the global questions asked on the first page of the materials. The only difference between the first set of questions and this second set is the change in specificity. Thus, where the first set asked about parents in general, the second set asked specifically about Joseph's parents. The rest of the question wording was identical. Whereas the first set of questions asked for agreement ratings with "Parents are to blame when their child breaks the law," the second set states "Joseph's parents are to blame for the crime he committed."

Results

Based on the results from the manipulation check, 17 participants were removed from further analyses because their responses indicated that they had not read the case description or that they did not perceive the premeditated versus not-premeditated conditions as intended. The remaining 151 participants were used in the following analyses.

Despite the use of a college student sample, similar responses were obtained for the current global questions as were found with the Gallup poll data (Brank \& Weisz, 2004). Once again, approximately 70\% of participants chose the parents as the most responsible in addition to the teenager. Slightly less than $30 \%$ thought that the peers were responsible, and approximately $1 \%$ thought that the media were responsible. 
To test effects of the premeditation manipulation, a series of three independent-sample $t$ tests were performed for each of the dependant variables of blame, responsible, and punish. Because this was a test of the case manipulation, the specific questions about Joseph's parents were employed in these tests. No significant differences were present between the responses of those who read about the premeditated crime and those who read about the nonpremeditated crime for blame, $t(149)=1.71, p=0.09, \eta^{2}=0.02$; responsible, $\left.t(149)=0.50, p=0.62, \eta^{2}<0.01\right)$; or punish, $t(149)=-0.34, p=0.74, \eta^{2}<$ 0.01 . For this reason, the results from this point forward will be discussed in the aggregate, and not divided based on the premeditation condition.

Using paired-sample $t$ tests, statistically significant differences were present between the global and specific attitudes of blame, with the global question $(\mathrm{M}=2.90, \mathrm{SD}=0.91)$ having higher agreement ratings than the specific question $(\mathrm{M}=2.56, \mathrm{SD}=0.98)$; $t(150)=4.72, p<0.001, \eta^{2}=0.12$. Responsible also had significantly different agreement ratings, once again with global $(\mathrm{M}=3.40, \mathrm{SD}=0.96)$ having higher agreement ratings than specific $(\mathrm{M}=3.03, \mathrm{SD}=1.05), t(150)=5.33, p<0.001, \eta^{2}=0.17$. Global and specific ratings were not significantly different for punishment, $t(150)=0.20, \mathrm{p}$ $=0.845, \eta^{2}=0.001$.

When asked to indicate which punishment was most appropriate for parents in general, approximately $41 \%$ said that no punishment was appropriate. Monetary fine received the next highest support at 36\%. Several participants $(26 \%)$ volunteered that some other form of punishment was appropriate, with most of those suggesting parenting classes or counseling.

Comparing these global responses to the specific responses about Joseph's parents, a similar trend emerged. For the specifically described juvenile, 44\% said that they felt no punishment was appropriate for his parents. Virtually all of the remaining responses indicated slightly less support for the specific versions of each of the punishment options (see Table 1).

\section{Discussion}

As predicted, participants found parents more blameworthy and more responsible for their children's behaviors when the issue was considered globally, rather than when considered in light of specific case facts. This difference was present even though the global measures were presented immediately prior to the rather short case description and the specific measures followed immediately after the description. Additionally, the global attitudes of this college student sample were very similar to those found by Brank and Weisz (2004) in a national Gallup poll. 
Table 1

Global and Specific Support for the Most Appropriate Punishment in the Current Study

\begin{tabular}{lrrrrr} 
& \multicolumn{2}{c}{ Global } & & \multicolumn{2}{c}{ Specific } \\
\cline { 2 - 3 } & $N$ & $\%$ & & $\%$ \\
\hline Monetary fine $^{\mathrm{a}}$ & 154 & 36 & & 37 & 25 \\
Prison $^{\mathrm{b}}$ & 8 & 5 & & 4 & 3 \\
Victim restitution $^{\mathrm{b}}$ & 25 & 17 & & 17 & 11 \\
Other $^{\mathrm{c}}$ & 39 & 26 & & 42 & 28 \\
No punishment $^{\mathrm{d}}$ & 62 & 41 & & 67 & 44 \\
\hline
\end{tabular}

Note. Participants were instructed to "Circle all that apply" for these questions; therefore, the percentages reflect the percentage of the total.

${ }^{a} X^{2}(1, N=151)=33.99, p<0.001$.

bUnable to calculate chi square because expected counts were too low.

${ }^{c} X^{2}(1, N=151)=39.53, p<0.001$.

${ }^{\mathrm{d}} X^{2}(1, N=151)=46.55, p<0.001$.

The presence or absence of the juvenile's premeditation in the case description had no effect on attitudes toward the parents. The answers to the manipulation-check question indicated that participants were able to distinguish between the present and absent premeditation conditions. Nonetheless, and in contrast to expectations, this case characteristic did not affect the change in attitudes toward the juvenile's parents.

\section{General Discussion}

The studies described here found a relatively low level of support for specific parental responsibility and blame, with even less support for parental punishment. The study that directly compared global and specific attitudes found less support for holding specific parents responsible for their children's action than for generally holding parents responsible. These results reinforce previous global and specific distinctions found across a number of criminal justice issues. 
Few politicians are willing to risk their political futures by ignoring the will of the people (McCorkle, 1993). In recent decades, we have witnessed the response of legislators to the apparent public outcry for more punitive sanctions (McCorkle, 1993; Samuel \& Moulds, 1986) and more responsibility placed on parents of juvenile offenders. The news media provide us with more and more examples of citizens crying out for parental responsibility (McHugh, 2003). Nonetheless, national polls have suggested that the public may not be as supportive as the media portray (Brank \& Weisz, 2004). The current research sought to go one step further by examining the possible differentiation between global and specific attitudes toward parental responsibility issues.

As hypothesized, those participants who read specific case descriptions had lower agreement with parental responsibility issues than did those who answered general questions without a case description. This finding is similar to previous results on other public-opinion issues (Applegate et al., 1996; Zamble \& Kahn, 1990). The complexity of attitudes toward crime and criminals (Moon, Wright et al., 2000) makes responses to global polls quite different from responses in specific situations. Quick one-or two-question polls elicit top-of-the-head reactions that do not reflect the appropriate level of attitude complexity (Applegate et al., 1996). People may think that they want harsh penalties in theory, but when they have read about a person, it becomes more difficult to support such harsh sanctions (Roberts, 1992).

Although there were similarities in opinions between the national sample (Brank \& Weisz, 2004) and the college students employed in the current study, the use of a college student sample limits the ability to make statements about national public opinion. Nonetheless, the current study addresses the issue of attitude differences between global and specific situations. The stimulus materials were brief, and the information provided about the parents was relatively neutral. Despite this artificiality, a clear distinction did emerge. A difference between global and specific attitudes toward parental responsibility was present, indicating that recent legislation may not accurately reflect the complex way the public views this issue.

Neither the pilot study nor the current study manipulated the description of the parents. The case descriptions both had neutral information about the parents. This was done as a reflection of current statutes and their lack of parental legal defenses (Brank et al., 2005). For civil laws, the minor's mental state is the only legally essential element. For criminal responsibility or involvement type laws, possible parental defenses rarely are included in the statutory language. Only in the contributing to delinquency type laws is parents' mens rea addressed. 
Regardless of the dearth of statutory attention toward parents' mental state, this is an area that may be important for future research. Indications from the current studies suggest that participants wanted to lay partial blame and responsibility on the parents, even when parental actions were not described as blatantly harmful. Is there a point at which the public would see the parental actions as so detestable that placing blame on parents would gain much greater support? Would the public distinguish between parental acts of commission and omission when determining blame for parents? It is clear that specific attitudes are different from global attitudes. What is unclear is if there are particular parental behaviors that would garner greater punitiveness toward parents.

In addition to global and specific differences, the current research also speaks to the media portrayal of a punishment-thirsty public. Although the limitations of the present studies caution against generalizing from the current sample, responses to the global measures in these studies suggest that there is not an overwhelming public desire to punish the parents of juvenile delinquents. While support for parental blaming and responsibility was consistently higher than was support for parental punishment, none of these notions gained an overwhelming endorsement with the current participant pool. Even when provided with punishment alternative options (e.g., victim restitution, community service, counseling), many of the respondents still felt that no response toward the parents was the most appropriate. This is in contrast not only to the media emphasis on parental responsibility, but also to the legislative attention that these ideas have received recently (Brank et al., 2005).

We live in a time and a nation in which public opinion matters (Kingdon, 1995). We are inundated with political debates and media articles citing public polls. What is clear from the global and specific line of research is that these global polls complicate public sentiments toward issues such as crime and criminals. Similarly, public attitudes toward parental responsibility are complex, and the media and political representations of a nation eager to hold individual parents responsible for the delinquent acts of their children appear to be misleading. 


\section{References}

Applegate, B.K., F.T. Cullen and B.S. Fisher (2002). Public views toward crime and correctional policies: is there a gender gap? Journal of Criminal Justice 30: 89-100.

Applegate, B.K., F.T. Cullen, M.G. Turner and J.L. Sundt (1996). Assessing public support for three-strikes-and-you're-out laws: global vs. specific attitudes. Crime and Delinquency 42: 517-534.

Belkin, L. (1999, October 31). Parents blaming parents. New York Times, pp. 6, 61.

Brank, E.M., S.C. Kucera and S.A. Hays (2005). Parental responsibility statues: an organization and policy implications. Journal of Law and Family Studies 7: 1-55.

Brank, E.M., and V. Weisz (2004). Paying for the crimes of their youth: public support of parental responsibility laws. Journal of Criminal Justice 32: 465-475.

Breed v. Jones, 421 U.S. 519 (1975).

Brink, D.O. (2004). Immaturity, normative competence, and juvenile transfer: how (not) to punish minors for major crimes. Texas Law Review 82: 1,555-1,585.

Cann, A., L.G. Calhoun and J.W. Selby (1980). Attributions for delinquent behavior: impact on consequences and consistency information. British Journal of Social and Clinical Psychology 19: 33-40.

Cumberland, J., and E. Zamble (1992). General and specific measures of attitudes toward early release of criminal offenders. Canadian Journal of Behavioral Sciences and the Law 24: 442-455.

Davidson, H. (1996). No consequences: re-examining parental responsibility laws. Stanford Law and Policy Review 7: 23-30.

Elliott, A. (2003). Nine are injured in fight at a roller rink. New York Times, p. B3.

Feld, B.C. (1991). The transformation of the juvenile court. Minnesota Law Review 75: 691-725.

Feld, B.C. (1999). The transformation of the juvenile court. Part II: Race and the "crack down" on youth crime. Minnesota Law Review 84: 327-395.

Gardner, M.R. (2003). Understanding Juvenile Law. (2nd ed.). New York: LexisNexis. Geis, G., and A. Binder (1991). Sins of their children: parental responsibility for juvenile delinquency. Notre Dame Journal of Law, Ethics, and Public Policy 5: 303-322.

Grisso, T., L. Steinberg, J. Wooldard, E. Cauffman, E. Scott and S. Graham, et al. (2003). Juveniles' competence to stand trial: a comparison of adolescents' and adults' capacities as trial defendants. Law and Human Behavior 27: 333-363.

Hanson, R.K. (1989). Parental liability. Wisconsin Lawyer 62: 24-28.

Hirschi, T., and M. Gottfredson (1993). Rethinking the juvenile justice system. Crime and Delinquency 39: 262-272.

Hollin, C.R., and K. Howells (1987). Lay explanations of delinquency: global or offense-specific? British Journal of Social Psychology 26: 203-210.

In re Gault, 387 U.S. 1 (1967).

In re Winship, 397 U.S. 358 (1970).

Kent v. United States, 383 U.S. 541 (1966). 
Kingdon, J.W. (1995). Agendas, Alternatives, and Public Policies. (2nd ed.). New York: HarperCollins College Publishers.

McCorkle, R.C. (1993). Punish and rehabilitate? Public attitudes toward six common crimes. Crime and Delinquency 39: 240-252.

McHugh, D.J. (2003, July 12). Parental guidance required. New York Times, p. A11.

Meredith, R. (1996, May 10). Parents convicted for a youth's misconduct. New York Times, p. A14.

Moon, M.M., J.L. Sundt, F.T. Cullen and J.P. Wright (2000). Is child saving dead? Public support for juvenile rehabilitation. Crime and Delinquency 46: 38-60.

Moon, M.M., J.P. Wright, F.T. Cullen and J.A. Pealer (2000). Putting kids to death: specifying public support for juvenile capital punishment. Justice Quarterly 17: 663684.

Public Agenda Online. (1999). Kids these days. Retrieved February 20, 2004, from http://www.publicagenda.org/specials/kids/kids3d.htm.

Roberts, J.V. (1992). Public opinion, crime, and criminal justice. Crime and Justice 16: 99-180.

Roberts, J.V. (2003). Public opinion and mandatory sentencing: a review of international findings. Criminal Justice and Behavior 30: 483-508.

Samuel, W., and E. Moulds (1986). The effect of crime severity on perceptions of fair punishment: a California case study. Journal of Criminal Law and Criminology 77: 931-948.

USA Today/CNN/Gallup Poll. (1999). On the Colorado school shootings. Retrieved February 20, 2004, from http://www.usatoday.com/news/poll016.htm.

Whiteside, S.P. and D.R. Lynam (2001). The five factor model and impulsivity: using a structural model of personality to understand impulsivity. Personality and Individual Differences 30: 669-689.

Zamble, E., and E. Kalm (1990). General and specific measures of public attitudes toward sentencing. Canadian Journal of Behavioral Science 22: 327-337.

Zolman, C.L. (1998). Parental responsibility acts: Medicine for ailing families and hope for the future. Capital University Law Review 27: 217-253. 